\title{
GaInAsSb Materials for Thermophotovoltaics
}

$$
\text { CONF-96/202-- }
$$

G. Charache, C. A. Wang, et. al.

December 1996

DISTRIBUTION OF THIS DOCUNENT IS UAMMTED

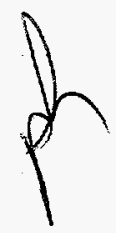

\section{MASTER}

\section{NOTICE}

This report was prepared as an account of work sponsored by the United States Government. Neither the United States, nor the United States Department of Energy, nor any of their employees, nor any of their contractors, subcontractors, or their employees, makes any warranty, express or implied, or assumes any legal liability or responsibility for the accuracy, completeness or usefulness of any information, apparatus, product or process disclosed, or represents that its use would not infringe privately owned rights. 


\section{DISCLAIMER}

This report was prepared as an account of work sponsored by an agency of the United States Government. Neither the United States Government nor any agency thereof, nor any of their employees, make any warranty, express or implied, or assumes any legal liability or responsibility for the accuracy, completeness, or usefulness of any information, apparatus, product, or process disclosed, or represents that its use would not infringe privately owned rights. Reference herein to any specific commercial product, process, or service by trade name, trademark, manufacturer, or otherwise does not necessarily constitute or imply its endorsement, recommendation, or favoring by the United States Government or any agency thereof. The views and opinions of authors expressed herein do not necessarily state or reflect those of the United States Government or any agency thereof. 


\section{DISCLAIMER}

Portions of this document may be illegible in electronic image products. Images are produced from the best available original document. 


\title{
GaInAsSb MATERIALS FOR THERMOPHOTOVOLTAICS*
}

\author{
C.A. WANG, G.W. TURNER, M.J. MANFRA, H.K. CHOI, AND D.L. SPEARS
}

Lincoln Laboratory, Massachusetts Institute of Technology, Lexington, MA 02173

\begin{abstract}
$\mathrm{Ga}_{1-\mathrm{x}} \mathrm{In}_{\mathrm{x}} \mathrm{As}_{1-\mathrm{y}} \mathrm{Sb}_{\mathrm{y}}(0.06<\mathrm{x}<0.2,0.05<\mathrm{y}<0.18)$ epilayers were grown latticematched to GaSb substrates by organometallic vapor phase epitaxy (OMVPE) and molecular beam epitaxy (MBE). For lattice-matched alloys, mirror-like surface morphologies were obtained by both OMVPE and MBE. The $4 \mathrm{~K}$ photoluminescence (PL) of all layers had a fullwidth at half-maximum (FWHM) of less than $10 \mathrm{meV}$ for PL peak emission $<1.9 \mu \mathrm{m}$. PL FWHM increased to $30 \mathrm{meV}$ for peak emission $-2.12 \mu \mathrm{m}$ for OMVPE-grown layers. Nominally undoped layers are p-type with typical $300 \mathrm{~K}$ hole concentration of $\sim 9 \times 10^{15} \mathrm{~cm}^{-3}$ and hole mobility $\sim 450$ to $580 \mathrm{~cm}^{2} / \mathrm{V}$-s for OMVPE-grown layers. $\mathrm{p}$ - and $\mathrm{n}$-type doping is reported for layers grown with either technique. The ideality factor of diode structures is -2 for both techniques.
\end{abstract}

\section{INTRODUCTION}

Thermophotovoltaic systems in which thermal radiation is converted to electricity through the use of a photovoltaic cell, are experiencing revived interest as the properties of low-bandgap semiconductor materials continue to improve [1]. To achieve high utilization of thermal radiation, the semiconductor cutoff wavelength should closely match the dominant wavelength of the thermal source. For TPV systems operating in the temperature range 1100 to $1500 \mathrm{~K}$, the peak in emissive power varies from 1.9 to $2.6 \mu \mathrm{m}$. This wavelength range can be satisfied by $\mathrm{Ga}_{1-x} \mathrm{In}_{\mathrm{x}} \mathrm{As} \mathrm{s}_{\text {-y }} \mathrm{Sb}_{\mathrm{y}}$ alloys which can be grown lattice-matched to either InAs or GaSb substrates. However, this alloy system exhibits a large miscibility gap [2,3] which limits the equilibrium growth of stable alloys to a cutoff wavelength of $2.39 \mu \mathrm{m}$ [4]. By using nonequilibrium growth techniques such as molecular beam epitaxy (MBE) and organometallic vapor phase epitaxy (OMVPE), metastable alloys can be grown $[5,6]$. In this paper, we report the growth $G a_{1-x} I_{x} A s_{1-y} S_{y}$ alloys by OMVPE and MBE and describe the materials properties as the alloy composition approaches the immiscibility region. We also discuss diode characteristics as they relate to the performance of TPV cells.

\footnotetext{
*This work was sponsored by the Department of Energy under AF Contract No. F19628-95-C()(0)2. The opinions, interpretations, conclusions and recommendations are those of the author and are not necessarily endorsed by the United States Air Force.
} 


\section{EPITAXIAL GROWTH, CHARACTERIZATION, AND DEVICE FABRICATION}

$\mathrm{Ga}_{1-\mathrm{x}} \mathrm{In}_{\mathrm{x}} \mathrm{As} \mathrm{s}_{1-y} \mathrm{Sb}_{\mathrm{y}}$ epilayers were grown on Te-doped $\mathrm{GaSb}$ or semi-insulating $\mathrm{GaAs}$ substrates by OMVPE and MBE. For OMVPE, solution trimethylindium (TMIn), triethylgallium (TEGa), tertiarybutylarsine (TBAs), and trimethylantimony (TMSb) were used as precursors with diethyltellurium (DETe) $\left(50 \mathrm{ppm}\right.$ in $\mathrm{H}_{2}$ ) and dimethylzinc (DMZn) (1000 $\mathrm{ppm}$ in $\mathrm{H}_{2}$ ) as $\mathrm{n}$ - and p-type doping sources, respectively. Layers were grown in a vertical rotating-disk reactor with the carrier gas $\mathrm{H}_{2}$ at a flow rate of $10 \mathrm{slpm}$ and reactor pressure of 150 Torr. TEGa, TBAs, and TMSb were selected as the organometallic precursors based on their low pyrolysis temperatures and minimal tendency toward adduct formation [7]. The group III mole fraction was typically 3.5 to $4 \times 10^{-4}$ which resulted in a growth rate of $2.7 \mu \mathrm{m} / \mathrm{hr}$. The V/III ratio was varied from 0.9 to 1.7 . Substrates were (100) oriented 2 degrees toward [110]. The growth temperature was $575^{\circ} \mathrm{C}$ for most layers, with some layers grown at 525 or $550^{\circ} \mathrm{C}$.

A solid-source $\mathrm{MBE}$ system with $\mathrm{Ga}$, In, $\mathrm{Sb}_{4}$, and $\mathrm{As}_{2}$ provided by a valved $\mathrm{As}$ cracker was used as described previously [8]. The growth temperature was $500-510^{\circ} \mathrm{C}$, and the growth rate was $\sim 1 \mu \mathrm{m} / \mathrm{hr}$. Be was used as the p-type dopant and $\mathrm{GaTe}$ as the n-type dopant.

The surface morphology was examined using Nomarski contrast microscopy. Carrier concentration and mobility of GaInAsSbSb epilayers, which were grown at least $3 \mu \mathrm{m}$ thick on semi-insulating GaAs substrates, were obtained from Hall measurements based on the van der Paluw method. Photoluminescence (PL) was measured at $4 \mathrm{~K}$. Double-crystal $\mathrm{x}$-ray diffraction (DCXD) was used to evaluate the structural quality and degree of lattice mismatch to $\mathrm{GaSb}$ substrates. The composition of epilayers was determined from the room temperature energy gap dependence on composition as reported in reference [3]. Since band-tailing effects might be significant for low-band gap alloys, the room temperature energy was estimated by substracting $0.065 \mathrm{eV}$ from the $4 \mathrm{~K}$ PL peak energy.

Ohmic contacts to $\mathrm{p}$ - and $\mathrm{n}-\mathrm{GaSb}$ were formed by depositing $\mathrm{Ti} / \mathrm{Pt} / \mathrm{Au}$ and $\mathrm{Au} / \mathrm{Sn} / \mathrm{Ti} / \mathrm{Pu} / \mathrm{Au}$, respectively, and alloying at $300^{\circ} \mathrm{C}$. The I-V characteristics were measured on $500 \times 500 \mu \mathrm{m}$ devices that were cleaved.

\section{RESULTS}

Figure 1 shows the surface morphology of $2-\mu \mathrm{m}$-thick $\mathrm{Ga}_{1-\mathrm{x}} \mathrm{In}_{\mathrm{x}} \mathrm{As}_{1-\mathrm{y}} \mathrm{Sb}_{\mathrm{y}}$ layers of various compositions grown by OMVPE and MBE. The growth temperature was $575^{\circ} \mathrm{C}$ and the V/III ratio was 1.15. The surface morphology is mirror-like to the eye for each layer. However, Nomarski contrast microscopy revealed a wavy texture, similarly reported for MBEgrown layers [6], which increased with increasing In content. A smoother morphology could be sbtained by reducing the growth temperature to 550 or $525^{\circ} \mathrm{C}$. The morphology for the MBE- 
grown layers which was also mirror-like did not change with various alloy compositions. The layers shown here are closely matched to the GaSb substrate with a lattice-mismatch $\Delta \mathrm{a} / \mathrm{a}<1.5$ $\times 10^{-3}$. Layers with $\Delta a / a-3-4 \times 10^{-3}$ exhibited a crosshatch surface morphology. The surface morphology is sensitive to V/III as shown in Figure 2 for OMVPE layers grown with $\mathrm{TMIn} /(\mathrm{TEGa}+\mathrm{TMIn})=0.23$. Below a minimum V/III ratio, a metal-rich surface is obtained. Increasing V/III ratio above the minimum value of 1.05 resulted in an increased surface texture.

PL spectra measured at $4 \mathrm{~K}$ showed only a single peak. Results of full-width at halfmaximum (FWHM) as a function of PL peak emission $E_{p}$ are shown in Figure 3 along with data previously reported by OMVPE [5,9], MBE [10], and liquid phase epitaxy [11]. Narrow FWHM $(<10 \mathrm{meV})$ are obtained for all layers with energy transitions below $\sim 0.64 \mathrm{eV}$, but the PL spectra is broadened considerably for the OMVPE-grown layers with lower $E_{p}$. On the other hand, the FWHM for layers grown by MBE was not as sensitive to $E_{p}$.

DCXD scans for OMVPE-grown $\mathrm{Ga}_{0.9}{ }_{3} \mathrm{In}_{0.07} \mathrm{As}_{0.08} \mathrm{Sb}_{0.92}$ and

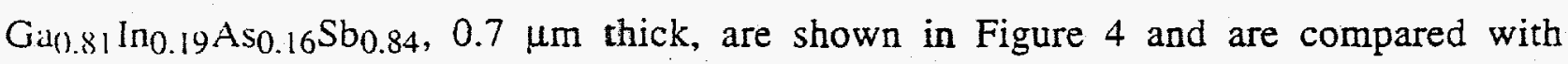
simulations based on the Taupin-Tagachi solution of dynamical $x$-ray diffraction. The scan for Gia(0.93 $I_{(0.07} \mathrm{As}_{0.08} \mathrm{Sb}_{0.92}$ shows Pendellosung fringes which are an indication of high structural quality. Conversely, the scan for Ga0.81 $\operatorname{In}_{0.19} \mathrm{As}_{0.16} \mathrm{Sb}_{0.84}$ shows a broadened $\mathrm{x}$-ray peak and loss of fringes, which might be an indication of alloy nonuniformity or clustering similar to observations in GaInAsSb grown near the miscibility gap [12]. Layers grown by MBE did not exhibit such $x$-ray broadening.

The electrical properties of GaInAsSb layers grown on SI GaAs substrates by OMVPE are shown in Figure 5. Since the lattice mismatch between GaInAsSb lattice matched to GaSb and GaAs is $8 \%$. growth was first initiated with a GaSb buffer layer grown at $550^{\circ} \mathrm{C}$. The hole concentration and mobility depended strongly on the presence of the GaSb buffer layer. These layers have a typical hole concentration of $-9 \times 10^{15} \mathrm{~cm}^{-3}$ and hole mobility $\sim 450$ to 580 $\mathrm{cm}^{2} / \mathrm{V}$-s. Nominally undoped GaInAsSb layers grown by MBE were p-type with a hole concentration of $2 \times 10^{16} \mathrm{~cm}^{-3}$, and hole mobiltiy of $\sim 300 \mathrm{~cm}^{2} / \mathrm{V}-\mathrm{s}$.

The electron and hole concentration of GaInAsSb layers grown by OMVPE are shown in Figure 6 for layers doped with DETe and DMZn, respectively. The electron concentration medsured at $300 \mathrm{~K}$ ranged from $3.4 \times 10^{17} \mathrm{~cm}^{-3}$ to $2.05 \times 10^{18} \mathrm{c} \mathrm{m}^{-3}$ with corresponding mobility values of $4640 \mathrm{~cm}^{2} / \mathrm{V}-\mathrm{s}$ and $1460 \mathrm{~cm}^{2} / \mathrm{V}-\mathrm{s}$, respectively. For $\mathrm{p}$-GainAsSb, the hole concentration measured at $300 \mathrm{~K}$ ranged from $7.8 \times 10^{16} \mathrm{~cm}^{-3}$ to $1.5 \times 10^{18} \mathrm{~cm}^{-3}$ with corresponding mobility values of 430 and $260 \mathrm{~cm}^{2} / \mathrm{V}$-s, respectively. For MBE-grown layers, the maximum electron concentration that has been obtained is $2 \times 10^{18} \mathrm{~cm}^{-3}$ with a mobility of 
$2300 \mathrm{~cm}^{2} / \mathrm{V}$-s, and the maximum thole concentration is $5 \times 10^{19} \mathrm{~cm}^{-3}$ with a mobility of $50 \mathrm{~cm}^{2} / \mathrm{V}$-s.

Test structures that consist of p-on-n GaInAsSb epilayers were grown to evaluate junction characteristics. Figure 7 shows the I-V curve for a typical device. The ideality factor at low current levels is -2.4 . There is a relatively large leakage current at low bias, which may be related to tunnelling [13]. However, it will not affect the performance of TPV cells which operate at very high current densities. The series resistance is relatively high because of the potential barriers at the n-GaSb substrate/n-GaInAsSb and p-GaInAsSb/p-GaSb interfaces.

\section{CONCLUSIONS}

GaInAsSb epilayers were grown lattice-matched to GaSb substrates by OMVPE and MBE. For OMVPE-grown layers, a degradation in the structural and optical properties was observed as the compostion of the alloy approached the miscibility gap. Layers grown by MBE, however, did not exhibit such changes. The series resistance of diode structures can be reduced by grading the interfaces and/or by heavily doping the interface regions.

\section{ACKNOWLEDGMENTS}

The authors gratefully acknowledge D.R. Calawa, J.W. Chludzinski, M.K. Connors, L. Krohn, R.J. Poillucci, and V. Todman-Bams for technical assistance, K.J. Challberg for manuscript editing, and B-Y. Tsaur for continued support and encouragement.

\section{REFERENCES}

1. 2nd NREL Conference on the Thermophotovoltaic Generation of Electricity, Colorado Springs, CO, AIP Conf. Proc. 3581995.

2. K. Onabe, Jpn. J. Appl. Phys. 21, p. 964 (1982).

3. J.C. DeWinter. M.A. Pollock, A.K. Srivastava, and J.L. Zyskind, J. Electron. Mater. 14, 729 (1985).

4. E. Tournie, F. Pitard, and A. Joullie, J. Cryst. Growth 104, p. 683 (1990).

5. M.J. Cherng, H.R. Jen, C.A. Larsen, G.B. Stringfellow, H. Lundt, and P.C. Taylor, J. Cryst. Growth 77, p. 408 (1986).

6. T.H. Chui, J.L. Zyskind, and W.T. Tsang, J. Electron. Mater. 16, p. 57 (1987).

7. C.A. Wang, J. Cryst. Growth to appear.

S. H.K. Choi. S.J. Eglash, and G.W. Turner, Appl. Phys. Lett. 64, p. 2474 (1994).

9. M. Sopanen. T. Koljonen, H. Lipsanen, and T. Tuomi, J. Cryst. Growth 145, p. 492 (1994).

10. S.J. Eglash and H.K Choi, Inst. Phys. Conf. Ser. No 120, p. 487 (1992). 
11. E. Tournie, J.-L. Lazzari, F. Pitard, C. Alibert, A. Joullie, and B. Lambert, J. Appl. Phys. 68. p. 5936 (1990).

12. A.G. Norman and G.R. Booker, J. Appl. Phys. 57, p. 4715 (1985).

13. G.W. Charache, J.L. Egley, L.R. Danielson, D.M. DePoy, P.F. Baldasaro, B.C. Campbell, S. Hui, L.M. Frass, and S.J. Wojtczuk, 26th Photovoltaic Specialist Conference. 


\section{FIGURE CAPTIONS}

Figure 1 Surface morphology of GaInAsSb epilayers grown on GaSb substrates by MBE (top) and OMVPE (bottom). Various compositions as indicated.

Figure 2 Surface morphology of OMVPE-grown GaInAsSb with various V/III ratios.

Figure 3 Full-width at half-maximum of $4 \mathrm{~K}$ photoluminescence spectra of GaInAsSb layers grown on $\mathrm{GaSb}$ substrates.

Figure 4 Double-crystal $x$-ray diffraction scans of a) $\mathrm{Ga}_{0.93} \mathrm{In}_{0.07} \mathrm{As}_{0.08} \mathrm{Sb}_{0.92}$ and b) $\mathrm{Ga}_{0.81} \mathrm{In}_{0.19} \mathrm{As} 0.16 \mathrm{Sb} 0.84$.

Figure 5 Electrical properties of nominally undoped GaInAsSb as a function of $\mathrm{GaSb}$ buffer layer thickness: a) hole concentration and b) hole mobility.

Figure 6 Dependence of a) electron concentration on diethyltellurium mole fraction and b) hole concentration on dimethylzinc mole fraction.

Figure $7 \quad \mathrm{I}-\mathrm{V}$ curve of $500 \times 500 \mu \mathrm{m}$ p-n GaInAsSb diode structure. 


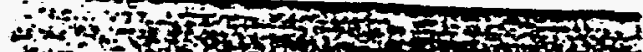

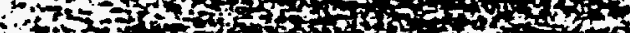

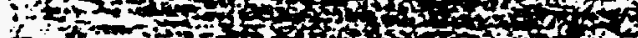
$6,-7$.

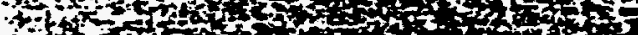

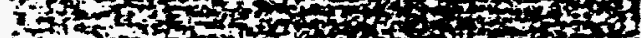

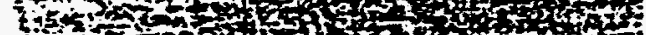

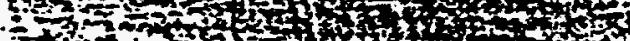

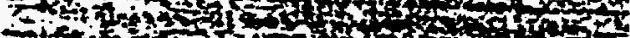

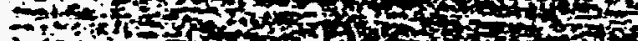

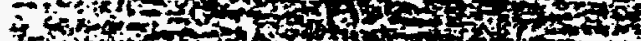

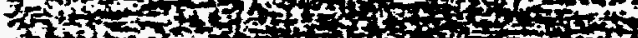

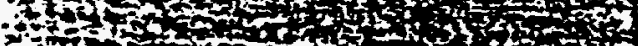

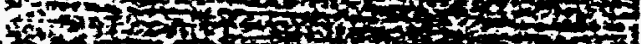

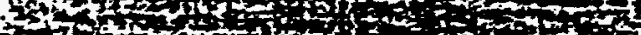

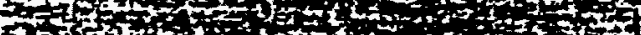

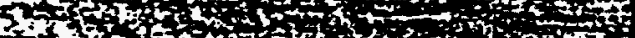

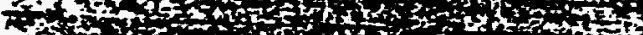

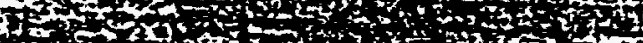

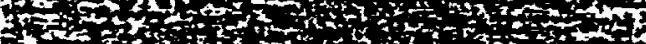

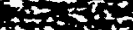

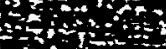

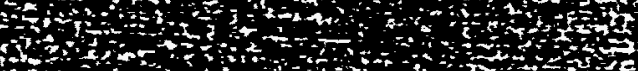

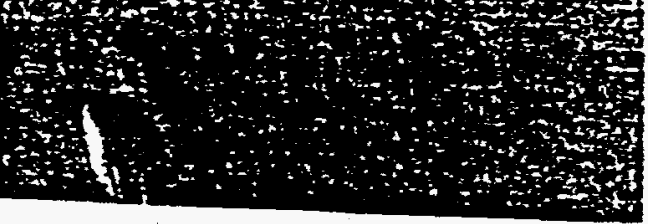

๓

8

क

T

i.

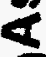

잉

을

5

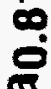

(b)
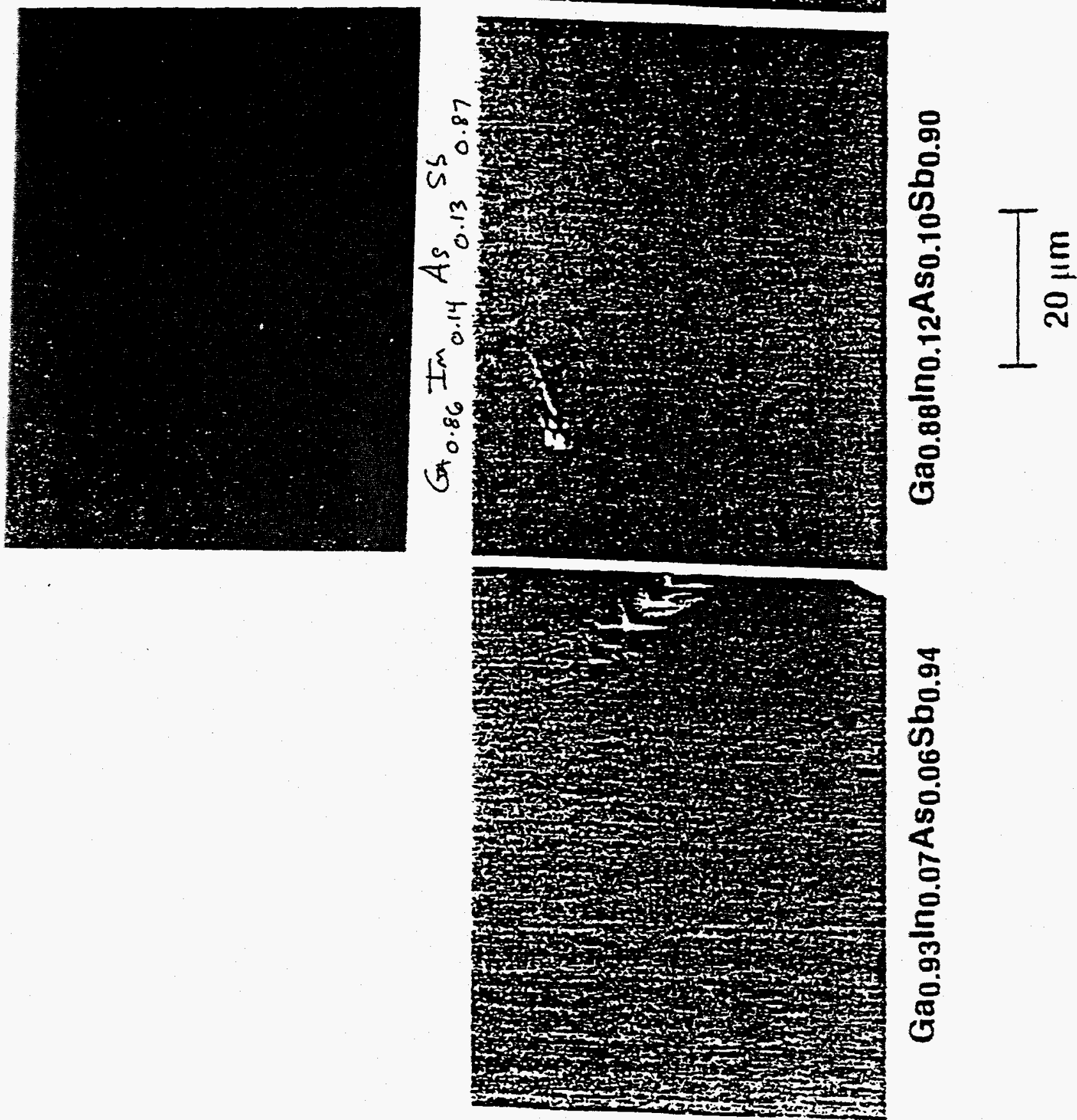

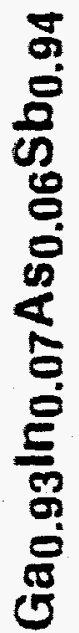




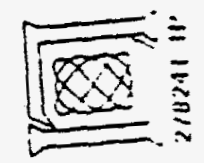
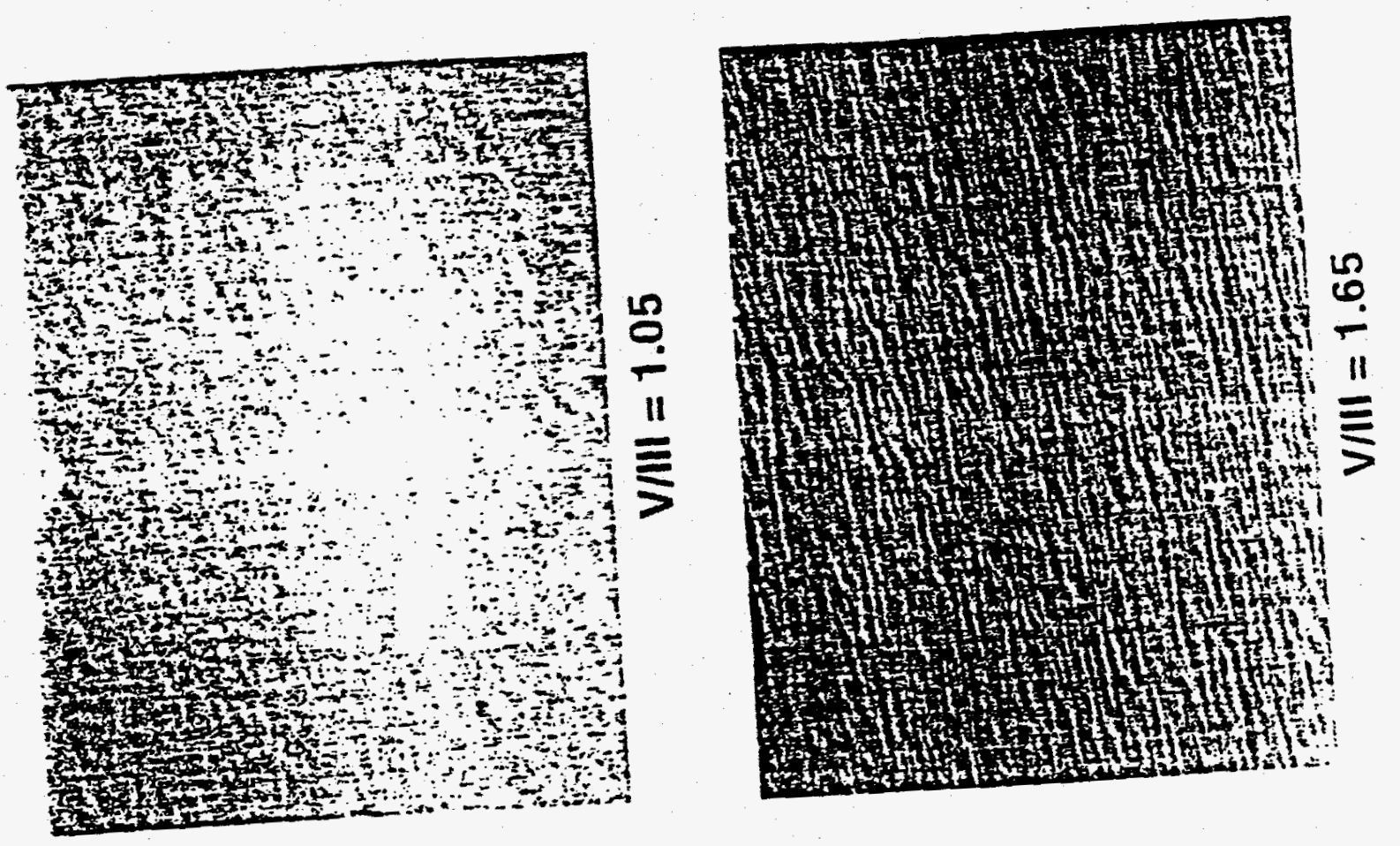

$\underset{D}{D}$
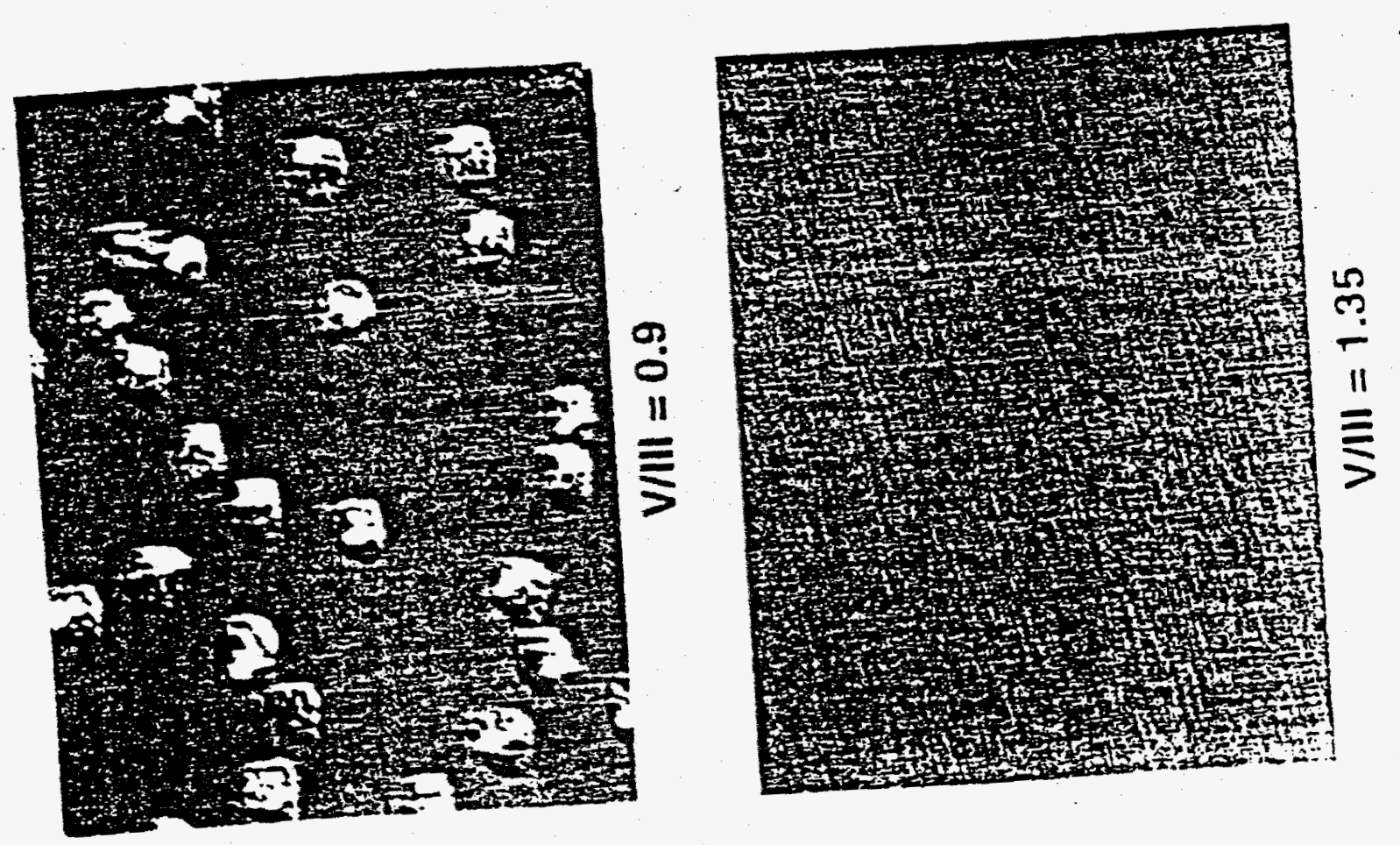

]$^{E}$ 


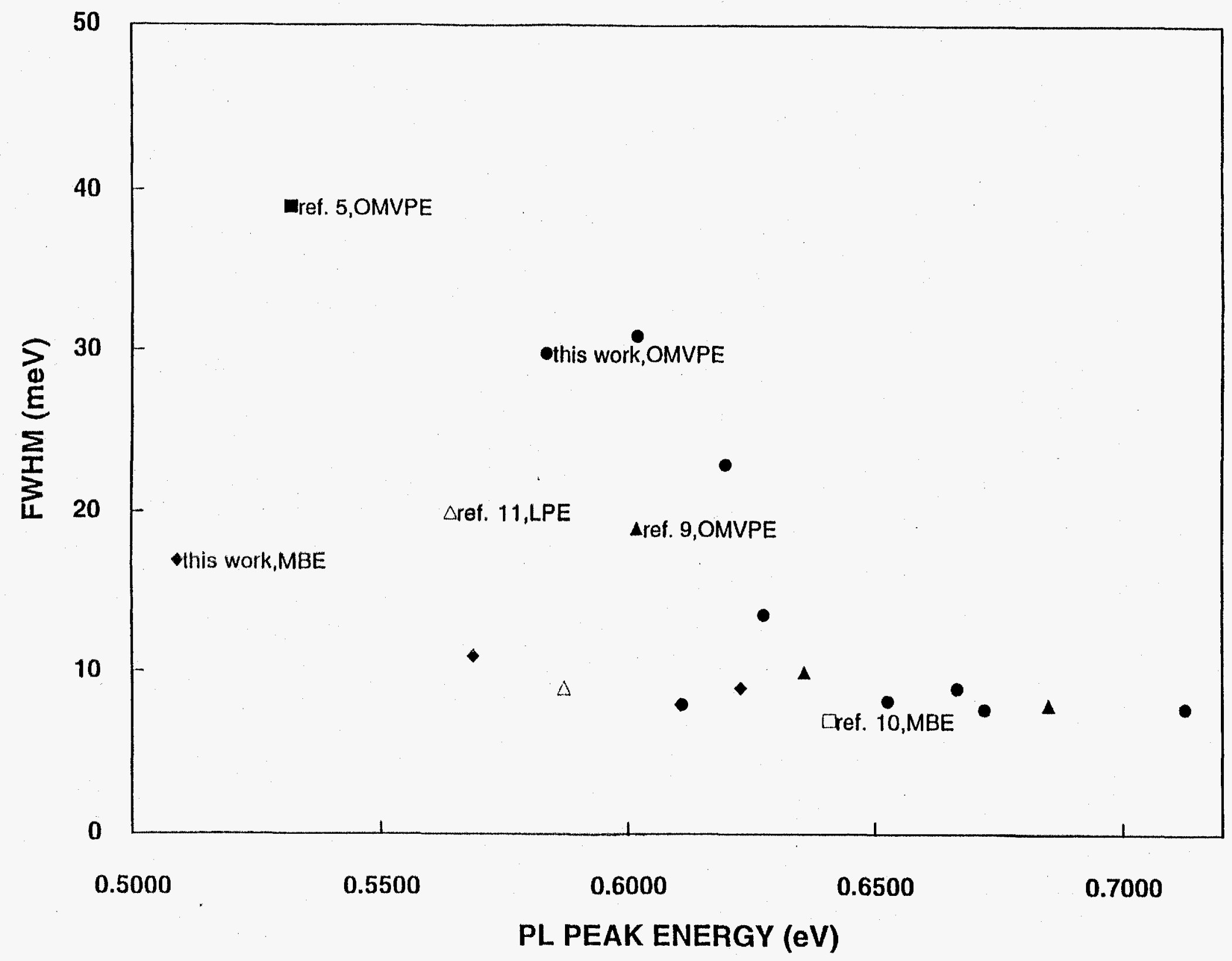

Figure 3 


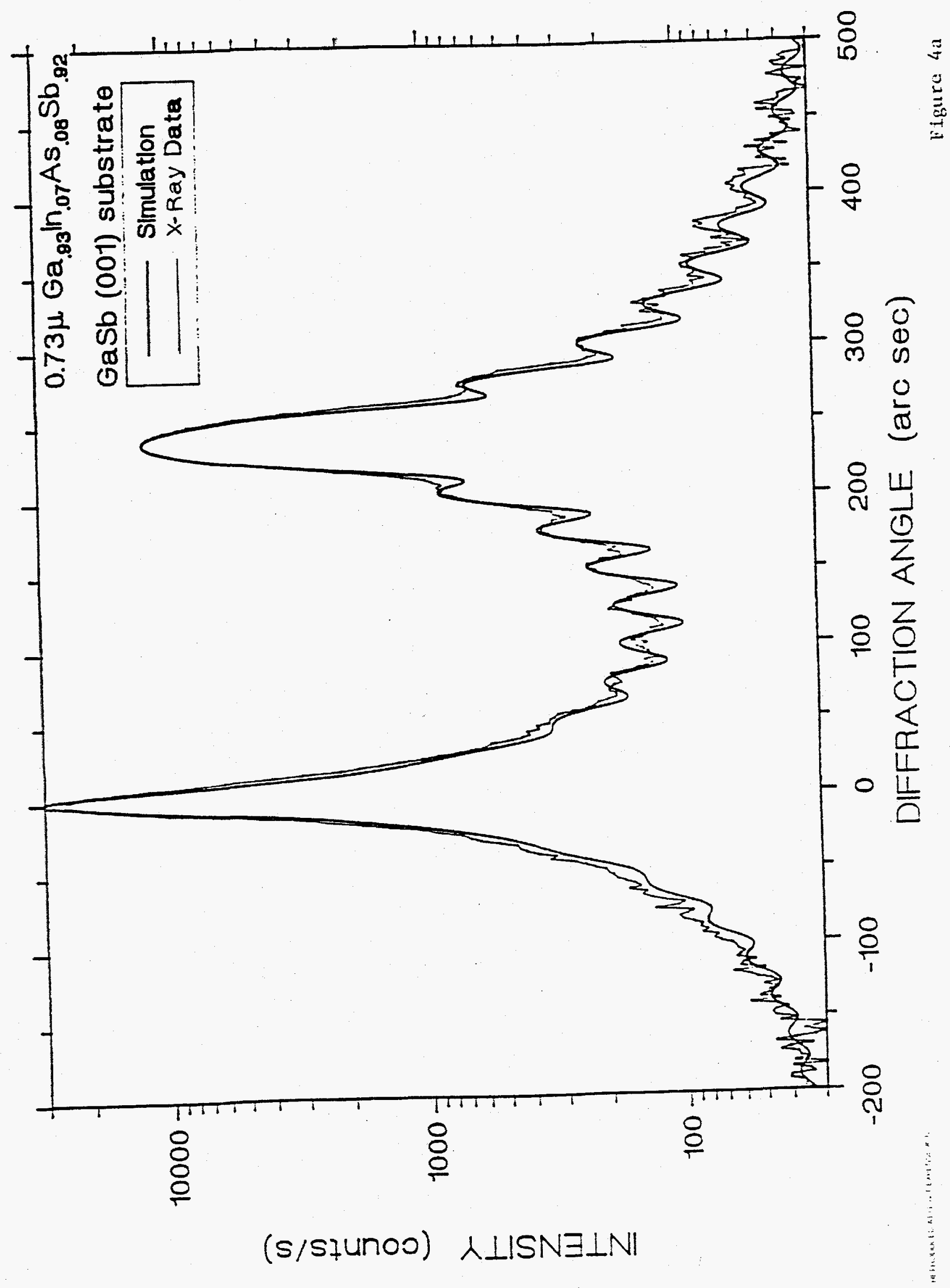




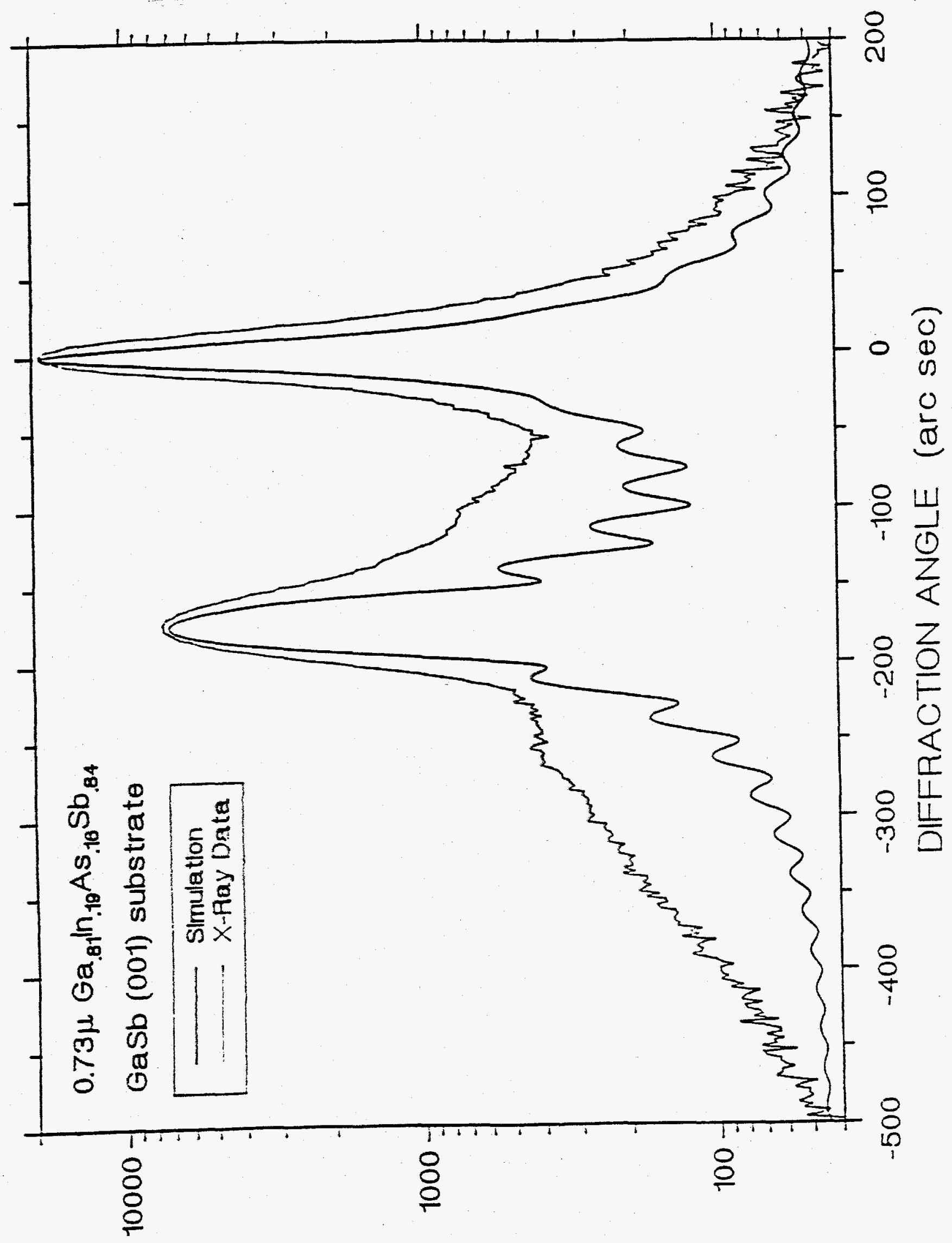

(s/siunoo) $\quad$ LISNE\NI 


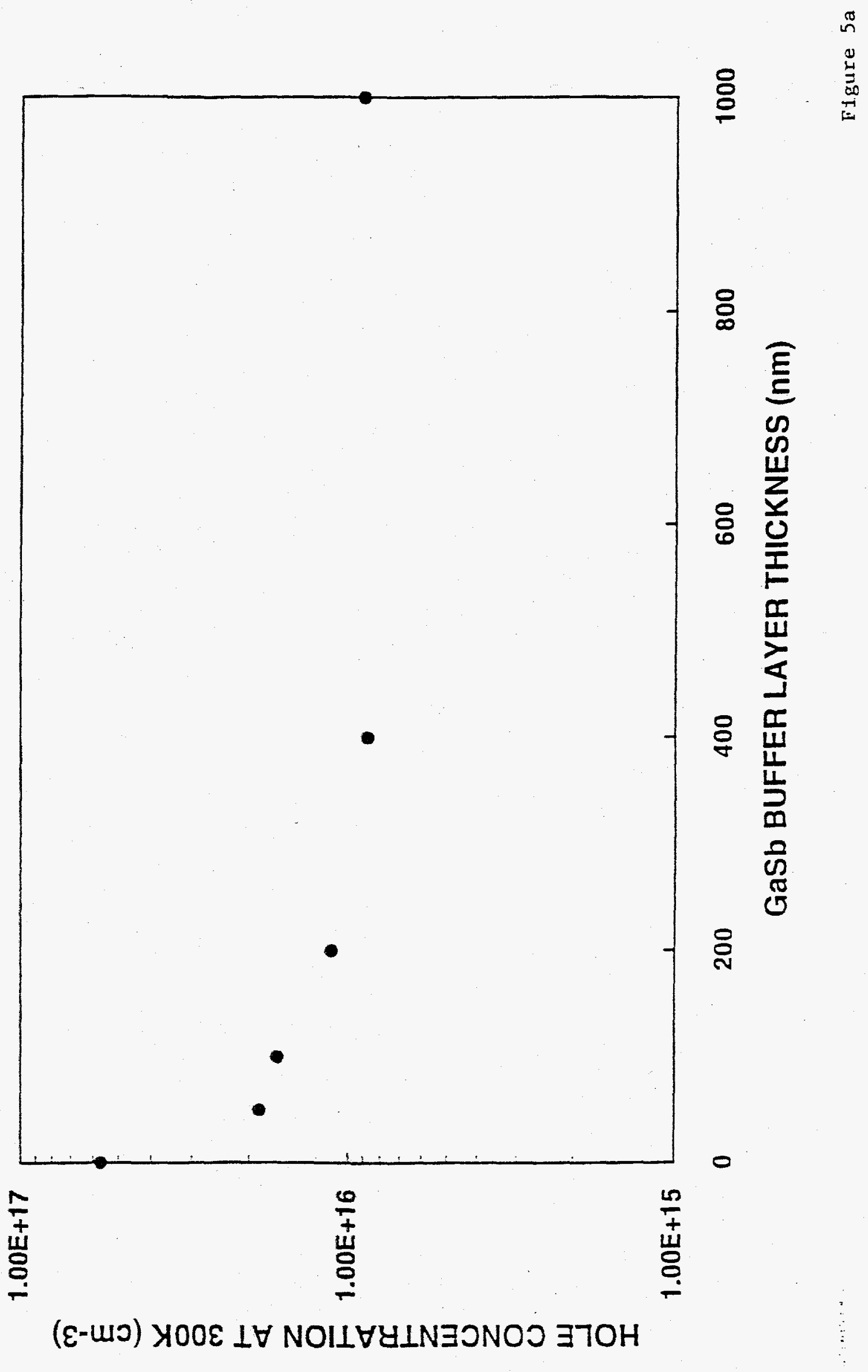




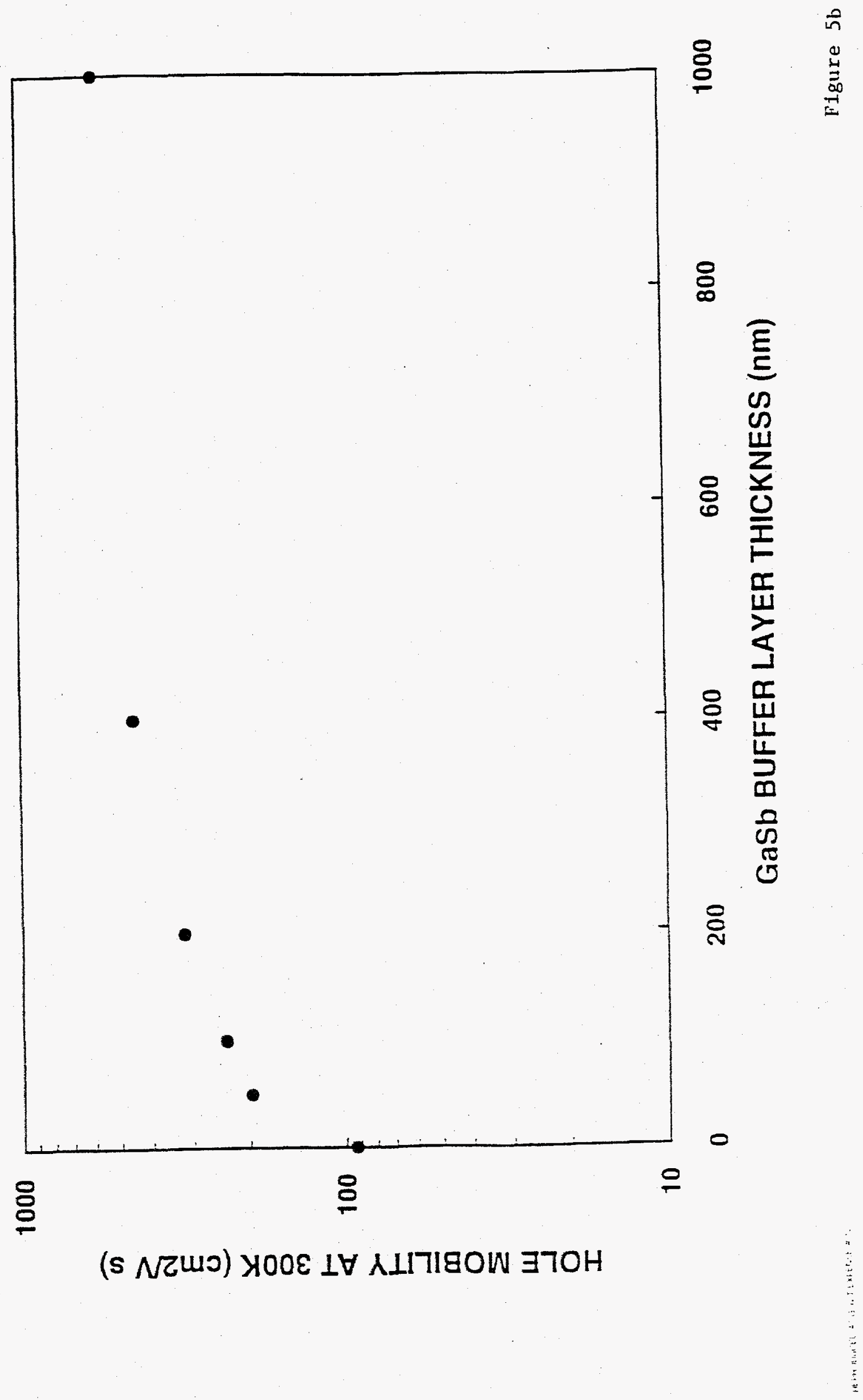




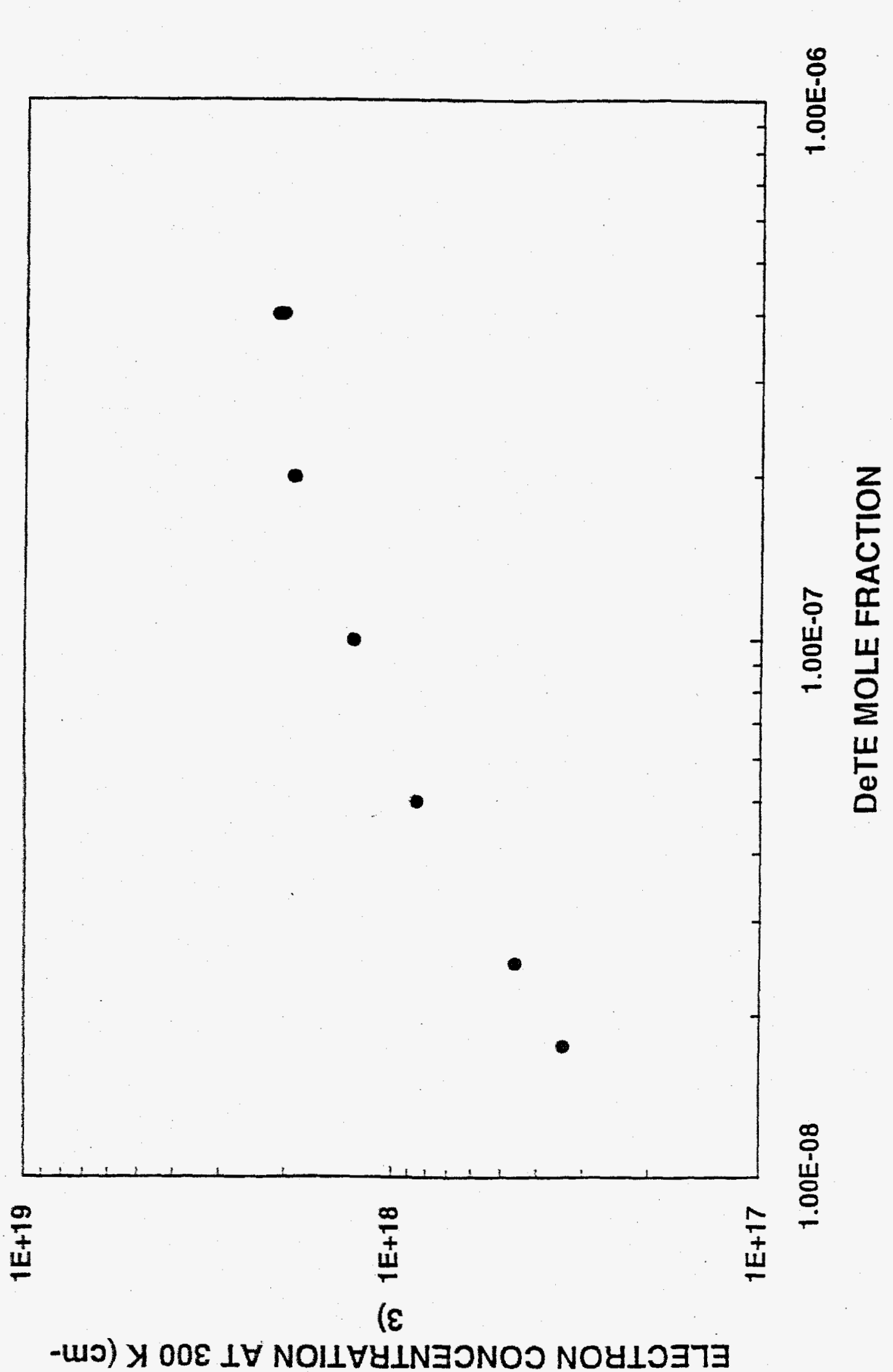




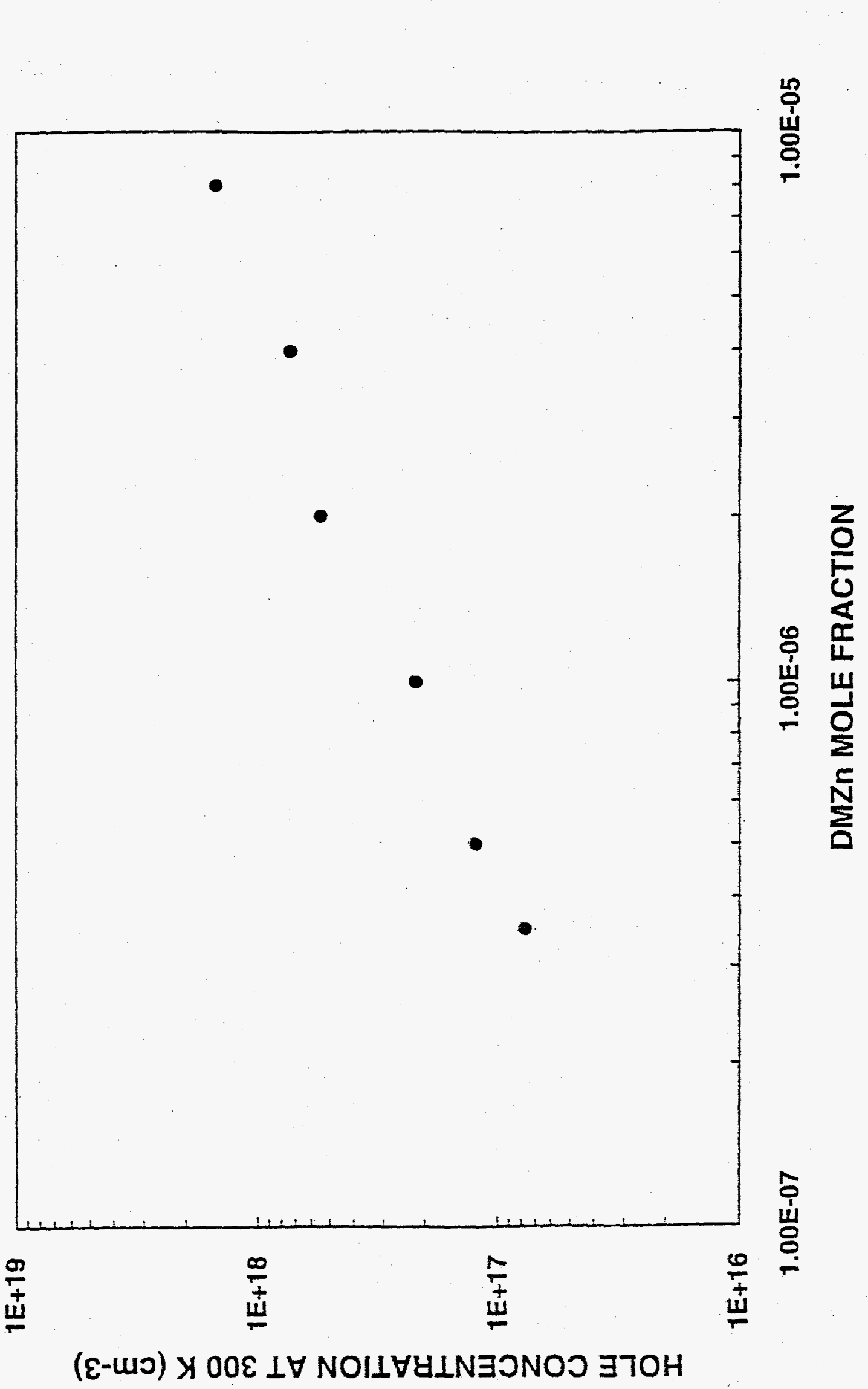




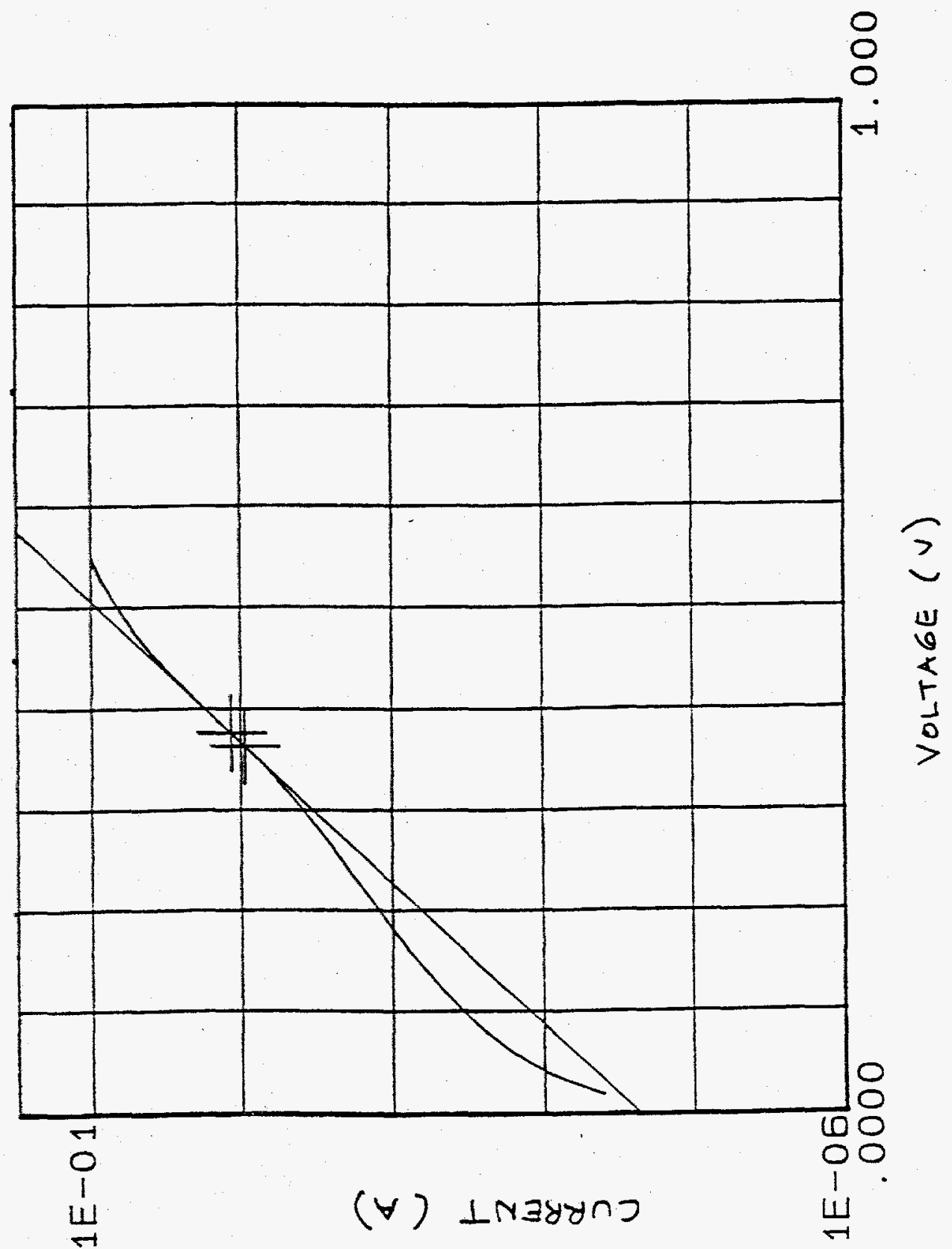

